NASA/TM-2004-213084
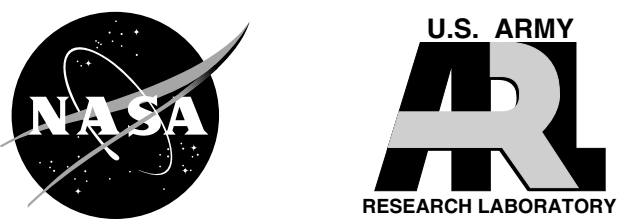

\title{
Effect of Surface Impulsive Thermal Loads on Fatigue Behavior of Constant Volume Propulsion Engine Combustor Materials
}

Dongming Zhu

U.S. Army Research Laboratory, Glenn Research Center, Cleveland, Ohio

Dennis S. Fox and Robert A. Miller

Glenn Research Center, Cleveland, Ohio

Louis J. Ghosn and Sreeramesh Kalluri

Ohio Aerospace Institute, Brook Park, Ohio 
Since its founding, NASA has been dedicated to the advancement of aeronautics and space science. The NASA Scientific and Technical Information (STI) Program Office plays a key part in helping NASA maintain this important role.

The NASA STI Program Office is operated by Langley Research Center, the Lead Center for NASA's scientific and technical information. The NASA STI Program Office provides access to the NASA STI Database, the largest collection of aeronautical and space science STI in the world. The Program Office is also NASA's institutional mechanism for disseminating the results of its research and development activities. These results are published by NASA in the NASA STI Report Series, which includes the following report types:

- $\quad$ TECHNICAL PUBLICATION. Reports of completed research or a major significant phase of research that present the results of NASA programs and include extensive data or theoretical analysis. Includes compilations of significant scientific and technical data and information deemed to be of continuing reference value. NASA's counterpart of peerreviewed formal professional papers but has less stringent limitations on manuscript length and extent of graphic presentations.

- TECHNICAL MEMORANDUM. Scientific and technical findings that are preliminary or of specialized interest, e.g., quick release reports, working papers, and bibliographies that contain minimal annotation. Does not contain extensive analysis.

- CONTRACTOR REPORT. Scientific and technical findings by NASA-sponsored contractors and grantees.
- CONFERENCE PUBLICATION. Collected papers from scientific and technical conferences, symposia, seminars, or other meetings sponsored or cosponsored by NASA.

- SPECIAL PUBLICATION. Scientific, technical, or historical information from NASA programs, projects, and missions, often concerned with subjects having substantial public interest.

- TECHNICAL TRANSLATION. Englishlanguage translations of foreign scientific and technical material pertinent to NASA's mission.

Specialized services that complement the STI Program Office's diverse offerings include creating custom thesauri, building customized databases, organizing and publishing research results ... even providing videos.

For more information about the NASA STI Program Office, see the following:

- Access the NASA STI Program Home Page at http://www.sti.nasa.gov

- E-mail your question via the Internet to help@sti.nasa.gov

- Fax your question to the NASA Access Help Desk at 301-621-0134

- Telephone the NASA Access Help Desk at 301-621-0390

- Write to:

NASA Access Help Desk

NASA Center for AeroSpace Information 7121 Standard Drive

Hanover, MD 21076 
NASA/TM-2004-213084

ARL-TR-3258
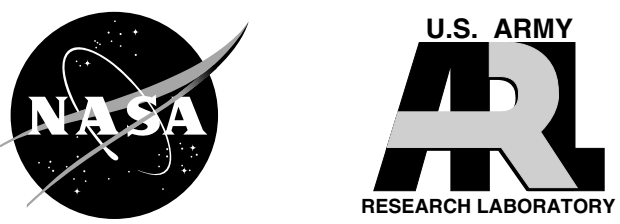

\section{Effect of Surface Impulsive Thermal Loads on Fatigue Behavior of Constant Volume Propulsion Engine Combustor Materials}

Dongming Zhu

U.S. Army Research Laboratory, Glenn Research Center, Cleveland, Ohio

Dennis S. Fox and Robert A. Miller

Glenn Research Center, Cleveland, Ohio

Louis J. Ghosn and Sreeramesh Kalluri

Ohio Aerospace Institute, Brook Park, Ohio

Prepared for the

International Conference on Metallurgical Coatings and Thin Films

sponsored by the AVS Science and Technology Society

Advanced Surface Engineering Division

San Diego, California, April 19-23, 2004

National Aeronautics and

Space Administration

Glenn Research Center 
Trade names or manufacturers' names are used in this report for identification only. This usage does not constitute an official endorsement, either expressed or implied, by the National Aeronautics and Space Administration.

\section{This work was sponsored by the Low Emissions Alternative}

Power Project of the Vehicle Systems Program at the NASA Glenn Research Center.

Available from

NASA Center for Aerospace Information 7121 Standard Drive

Hanover, MD 21076
National Technical Information Service 5285 Port Royal Road Springfield, VA 22100 


\title{
Effect of Surface Impulsive Thermal Loads on Fatigue Behavior of Constant Volume Propulsion Engine Combustor Materials
}

\author{
Dongming Zhu \\ U.S. Army Research Laboratory \\ Glenn Research Center \\ Cleveland, Ohio 44135 \\ Dennis S. Fox and Robert A. Miller \\ National Aeronautics and Space Administration \\ Glenn Research Center \\ Cleveland, Ohio 44135 \\ Louis J. Ghosn and Sreeramesh Kalluri \\ Ohio Aerospace Institute \\ Brook Park, Ohio 44142
}

\begin{abstract}
Summary
The development of advanced high performance constant-volume-combustion-cycle engines (CVCCE) requires robust design of the engine components that are capable of enduring harsh combustion environments under high frequency thermal and mechanical fatigue conditions. In this study, a simulated engine test rig has been established to evaluate thermal fatigue behavior of a candidate engine combustor material, Haynes 188, under superimposed $\mathrm{CO}_{2}$ laser surface impulsive thermal loads (30 to $\left.100 \mathrm{~Hz}\right)$ in conjunction of the mechanical fatigue loads $(10 \mathrm{~Hz})$. The mechanical high cycle fatigue (HCF) testing of some laser pre-exposed specimens has also been conducted under a frequency of $100 \mathrm{~Hz}$ to determine the laser surface damage effect. The test results have indicated that material surface oxidation and creepenhanced fatigue is an important mechanism for the surface crack initiation and propagation under the simulated CVCCE engine conditions.
\end{abstract}

\section{Introduction}

Constant-volume-combustion-cycle engines (CVCCE) based on the pulsed detonation engine (PDE) concept have received increasing attention for future aerospace propulsion applications. Because the CVCCE is designed for a high frequency, intermittent detonation combustion process, extremely high gas temperature and pressure can be realized under the nearly constant-volume combustion environment. The CVCCEs can potentially achieve higher thermodynamic cycle efficiency and thrust density as compared to traditional constant-pressure combustion gas turbine engines [1]. However, the development of these engines requires robust design of the engine components that are capable of enduring harsh detonation environments. In particular, the detonation combustor chamber, which is designed to sustain and confine the detonation combustion process, will experience high pressure and temperature pulses with a very short duration [2,3]. Therefore, it is of great importance to evaluate engine combustor materials and components under simulated engine temperature and stress conditions in the laboratory. In this paper, a laser impulsive thermal and thermomechanial fatigue testing approach for evaluating materials to be used in CVCCE combustor applications is described. The failure mechanisms of a cobalt-base Haynes 188 combustor material under the simulated engine conditions are also presented. 


\section{Experimental}

A high cycle thermal fatigue test rig for evaluating CVCCE combustor materials has been established using a $1.5 \mathrm{~kW} \mathrm{CO}$ enhanced pulsed laser [4]. A diagram showing the three laser rig testing approaches employed is shown in fig. 1. The high power laser, when operating in the pulsed mode, can be controlled at various pulse energy levels and waveform distributions. The enhanced laser pulses can be used to mimic the time-dependent temperature and pressure waves encountered in a pulsed detonation engine. Under the enhanced laser pulse condition, a maximum $7.5 \mathrm{~kW}$ peak power with duration of approximately 0.1 to $0.2 \mathrm{~ms}$ (a spike) can be achieved, followed by a plateau region that has about $1 / 5$ of the maximum power level with several ms duration. The laser thermal fatigue rig has also been developed to adopt flat and rotating tubular specimen configurations for the simulated engine tests [4]. More sophisticated laser optic systems can be used to simulate the spatial distributions of the temperature and shock waves in the engine.

In this study, the pulse laser thermal high cycle fatigue (HCF) behavior has been investigated for the cobalt-base superalloy Haynes 188 specimens (dimension 50 by 50 by $1.0 \mathrm{~mm}$, with mechanically polished surfaces), under the test condition of $30 \mathrm{~Hz}$ cycle frequency [4]. In this laser thermal fatigue test, a Gaussian laser beam (with a radius of $16 \mathrm{~mm}$ and the above mentioned pulse characteristics) was used to provide the specimen heating and room temperature air was used for specimen backside cooling. Specimen temperatures were measured by two-color pyrometers. The specimens were tested under the high frequency laser pulses at an average surface temperature of $800{ }^{\circ} \mathrm{C}$ and the back temperature of $650^{\circ} \mathrm{C}$. Besides the laser thermal high cycle fatigue (HCF) testing, the specimens were also thermally cycled between the test temperatures and room temperature using 30 min hot cycles with 3 min cooling (low cycle fatigue or LCF).

In order to investigate the combustor cooling hole effect on the fatigue behavior of the candidate material, a combined thermal and mechanical four-point-bend test was also performed under the superimposed laser thermal HCF loads $(100 \mathrm{~Hz})$ in conjunction with the mechanical fatigue bending loads $(10 \mathrm{~Hz})$. The dimension of the bend test specimens used was 19 by 10 by $1.2 \mathrm{~mm}$, with the cooling hole diameter being 0.38 and $0.76 \mathrm{~mm}$, respectively. The specimen hole arrangement is shown in fig. 2 . The specimens were mechanically polished and then tested under the high frequency laser pulses at the average surface temperature of $650{ }^{\circ} \mathrm{C}$ and the back temperature of $500{ }^{\circ} \mathrm{C}$. The specimens were also thermally cycled between the test temperatures and room temperature using 30 min hot cycles with 3 min cooling.

The mechanical high cycle fatigue testing was also conducted for laser pulse treated tensile fatigue specimens under a frequency of $100 \mathrm{~Hz}$ (mechanical) at $816{ }^{\circ} \mathrm{C}$. The tensile fatigue specimens were mechanically polished so that the final polishing marks were in the longitudinal direction of the specimens to minimized surface roughness effect on the HCF behavior. The tensile fatigue specimens were all subjected to the laser thermal HCF pre-treatment at a surface average temperature ranging from 816 to $1010^{\circ} \mathrm{C}$ at $100 \mathrm{~Hz}$, with the laser $30 \mathrm{~min}$ cycle thermal LCF test conditions. The sequential laser and mechanical HCF tests were used to investigate the prior laser HCF surface damage effect on the subsequent HCF strength of the candidate material Haynes 188 alloy.

The laser induced impulsive temperature profiles, stress distributions and creep response in the test specimens are modeled using finite difference to help understand the thermal fatigue behavior of the materials system under the laser-enhanced HCF and LCF test conditions. The material failure mechanisms under the laser simulated CVCCE conditions are also presented in this paper.

\section{Experimental Results and Discussion}

Figure 3 shows the typical temperature response and distributions calculated using one-dimensional finite difference models for the Haynes 188 alloy specimen under the enhanced laser pulse thermal 


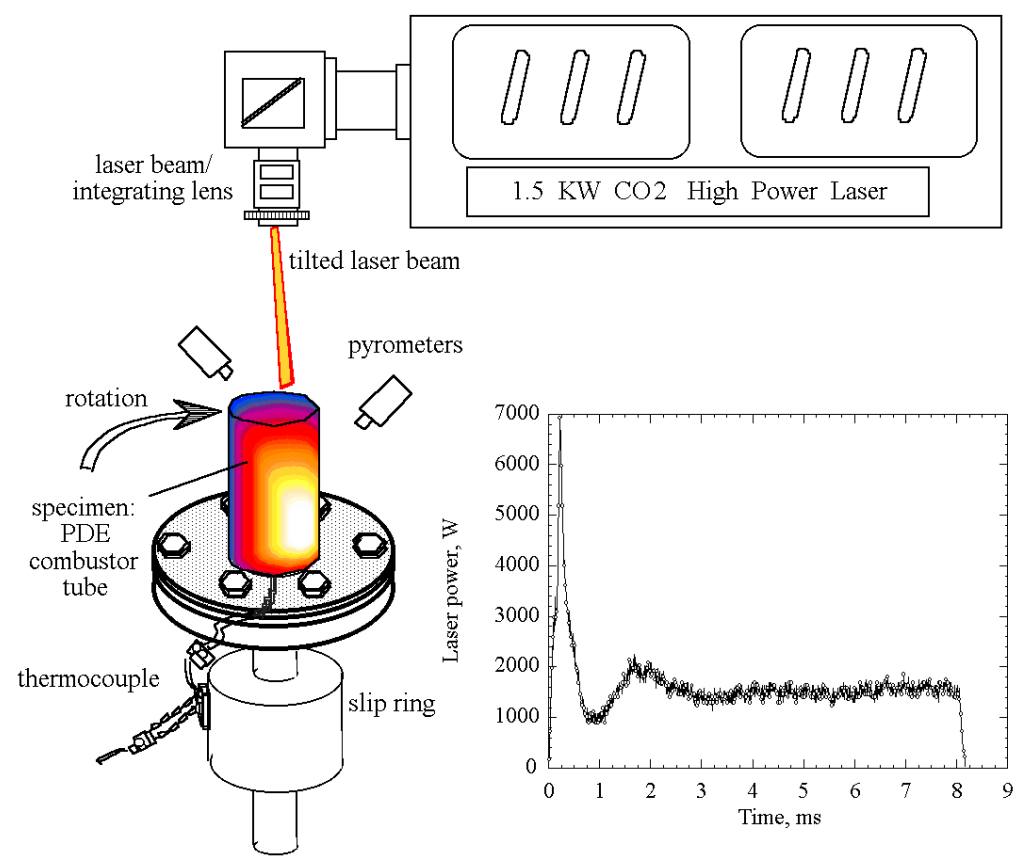

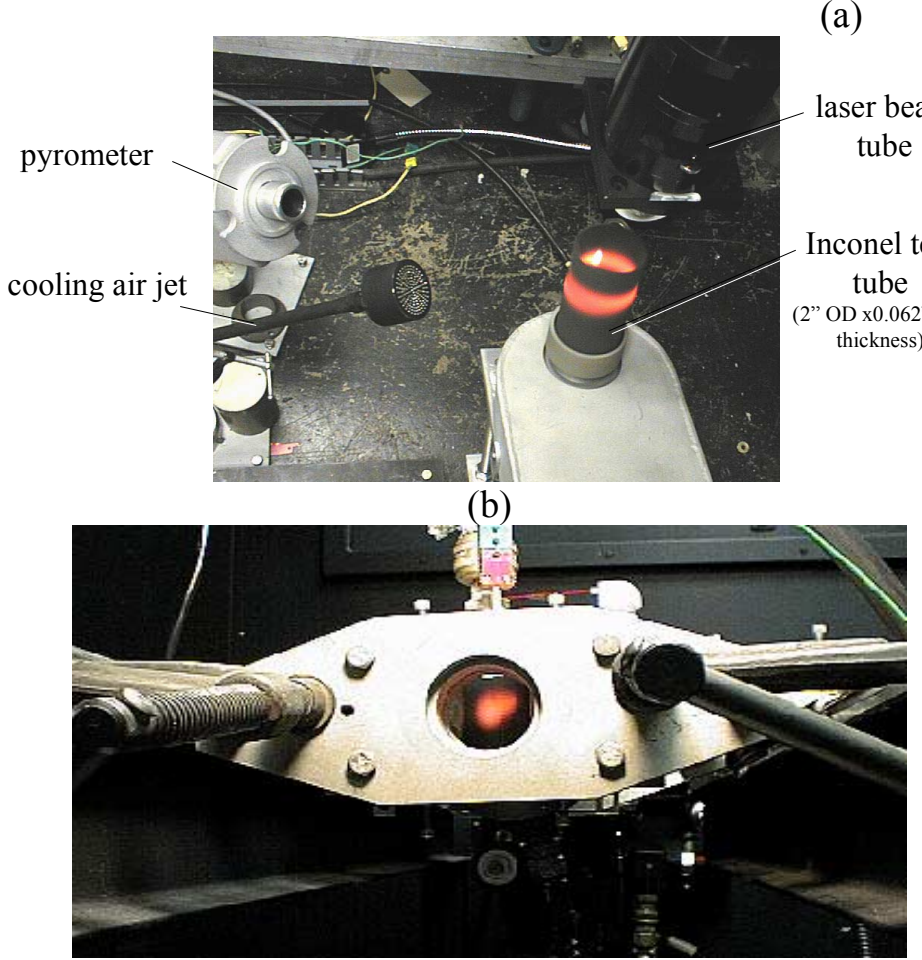

(c)

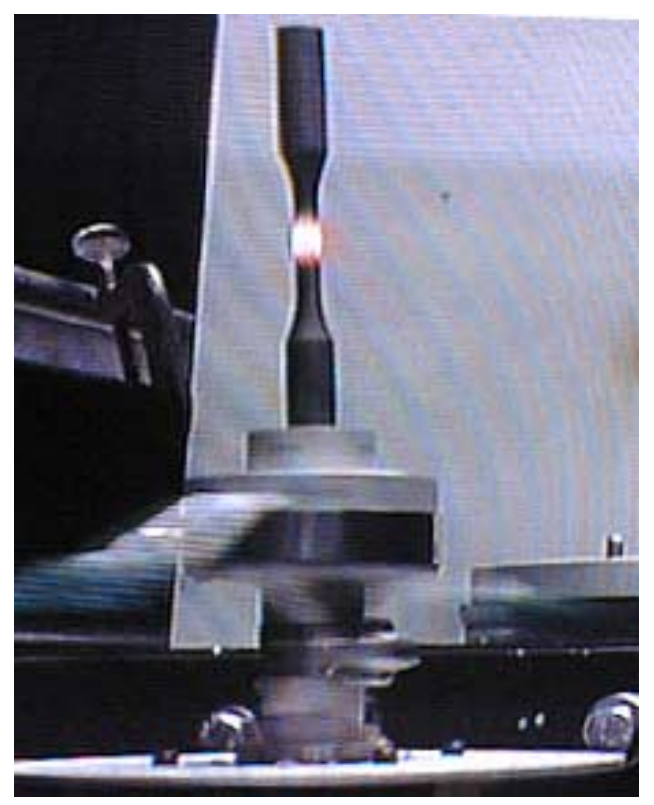

(d)

Figure 1.-A high power $\mathrm{CO}_{2}$ laser rig developed for testing $\mathrm{CVCCE}$ combustor materials and components under the simulated engine temperature and stress conditions. (a) Schematic diagram showing a laser test rig, and the measured laser pulse waveform from the pulse signal of a $1.5 \mathrm{KW}$ $\mathrm{CO}_{2}$ laser under the enhanced pulse mode using an oscilloscope. The laser pulse width is $8 \mathrm{~ms}$, and a maximum laser power $7.5 \mathrm{KW}$ can be achieved over about $0.2 \mathrm{~ms}$ duration at the pulse enhancement mode; (b) and (c) Tubular and flat specimen configurations adopted for the simulated CVCCE engine test, under thermal and/or combined (four point bend) mechanical fatigue thermal fatigue conditions; (d) Pulsed laser pre-testing of a mechanical high cycle fatigue (HCF) specimen. 


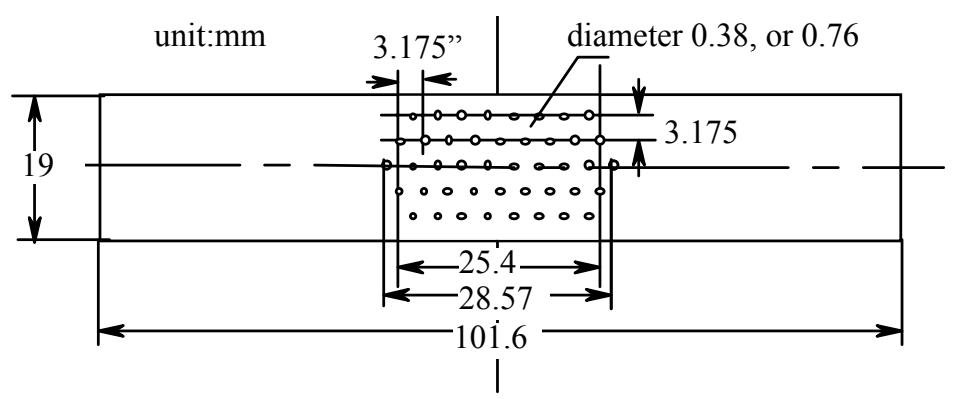

Figure 2.-Four-point-bend test specimen with center

holes arrangement for the combined laser

thermo-mechanical fatigue test.

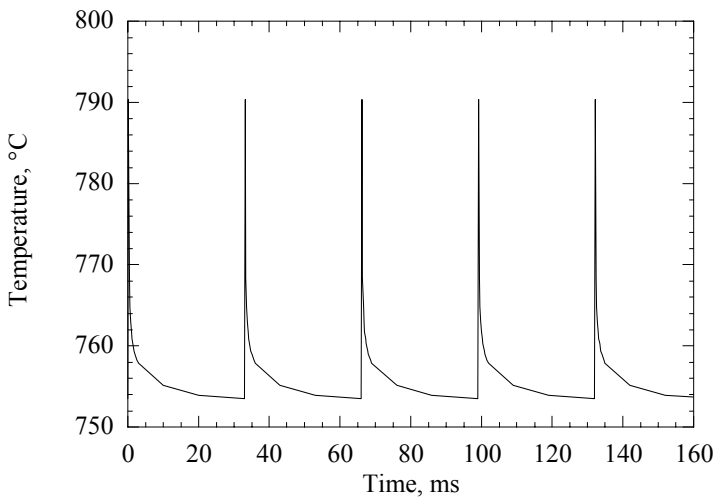

(a)

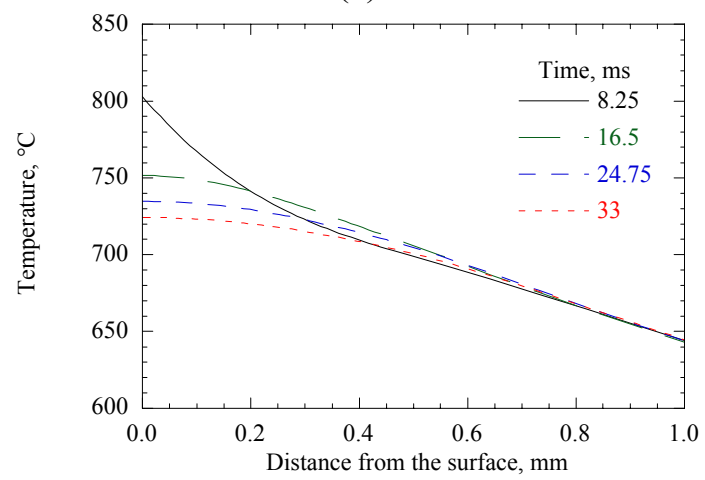

(c)

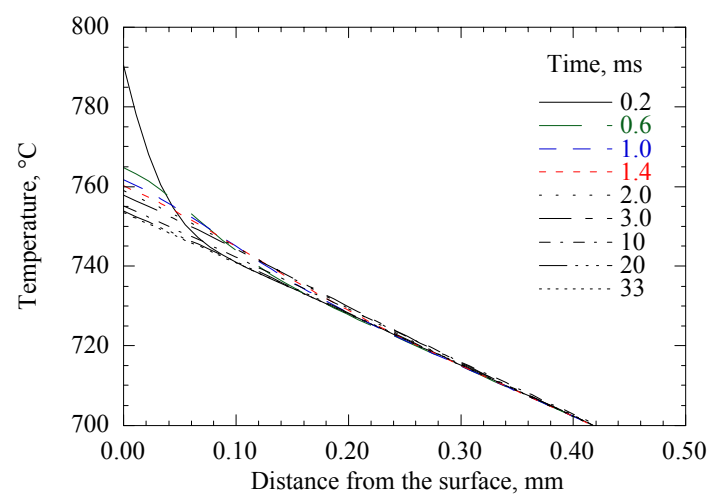

(b)

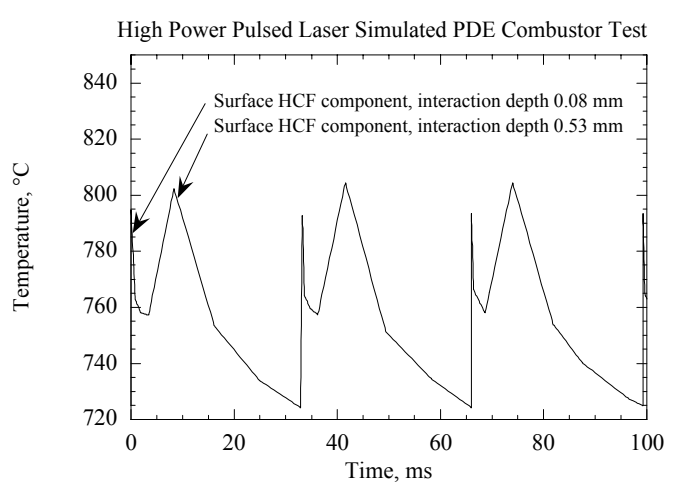

(d)

Figure 3.-One-dimensional finite difference modeling results showing the temperature swings on a Haynes 188 specimen under the $30 \mathrm{~Hz}$ enhanced pulse condition $(33 \mathrm{~ms}$ pulse period, $10 \mathrm{~ms}$ pulse width including $0.2 \mathrm{~ms}$ pulse spike). (a) Temperature pulses induced by the high energy laser pulse spike. (b) Temperature swings due to the enhanced, $0.2 \mathrm{~ms}$ laser pulse spike. (c) Temperature fluctuations due to the regular $10 \mathrm{~ms}$ laser pulse. (d) Superimposed temperature profiles during the enhanced pulse laser testing at the specimen surface.

fatigue test conditions. The numerical calculations show that that the enhanced $0.2 \mathrm{~ms}$ laser pulse spikes, which are used to simulate the CVCCE temperature and shockwave pulses, can cause a rapid cyclic temperature swing on the specimen surface, as shown in fig. 3 (a). In addition, an additional $40{ }^{\circ} \mathrm{C}$ temperature fluctuation with an interaction depth of $0.08 \mathrm{~mm}$ near the specimen surface region will be generated due to the enhanced $0.2 \mathrm{~ms}$ laser pulse spikes, as shown in the temperature distribution plot of 
fig. 3 (b). This enhanced pulsed temperature swing will be superimposed onto the temperature swing of $80{ }^{\circ} \mathrm{C}$ that is induced by the $10 \mathrm{~ms}$ regular laser pulse near the $0.53 \mathrm{~mm}$ deep surface interaction region (fig. 3 (c) and fig. 3 (d)).

Specimen failure modes were investigated after the laser thermal high cycle fatigue testing. As shown in fig. 4, extensive surface cracking with the crack depths of approximately $30 \mu \mathrm{m}$ was observed on the tested specimens under the enhanced laser pulses and thermal cycling. The surface crack morphologies of the specimen are further shown in fig. 5. As can be seen from fig. 5, under the oxidizing environments, oxide scales (typically $\mathrm{Cr}_{2} \mathrm{O}_{3}$ and $\mathrm{Ni}, \mathrm{Cr}$ spinel oxides) were formed on the Haynes 188 specimen surfaces. The carbide inclusions, which can initiate intergranular cracks [5], will also facilitate the fatigue crack propagation under the surface impulsive thermal loading. Significant alloy creep and fatigue, as indicated by the deformation, cracking and various length scale fatigue striations in the substrate near the oxide/alloy interfaces, were observed under the laser test conditions. The stresses originating from the large thermal gradients across the specimen, as well as the thermal expansion mismatch between the oxide scales and substrate under the laser HCF and LCF test conditions, resulted in the alloy creep deformation and later the surface cracking due to the oxidation-creep interaction under the complex cyclic stresses.

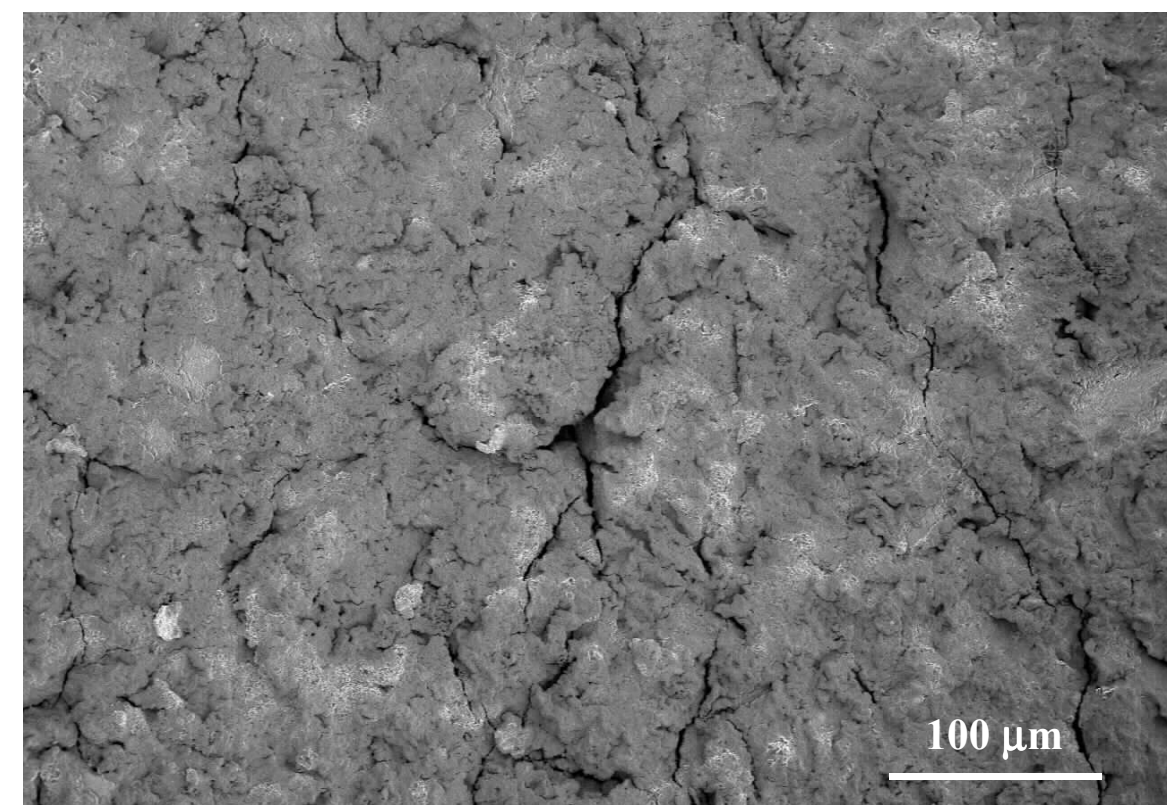

(a)

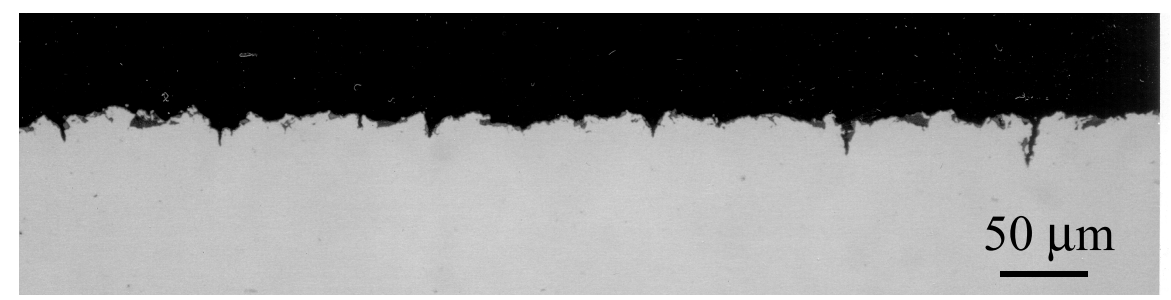

(b)

Figure 4.- Surface cracking patterns of the Haynes 188 superalloy after the $30 \mathrm{~Hz}$ enhanced laser pulses and thermal cycling (10.8 million $30 \mathrm{~Hz}$ high cycle fatigue cycles, and 20030 min-heating-cooling cycles). (b) Cross-section of tested specimen showing surface cracking penetration into the alloy. 


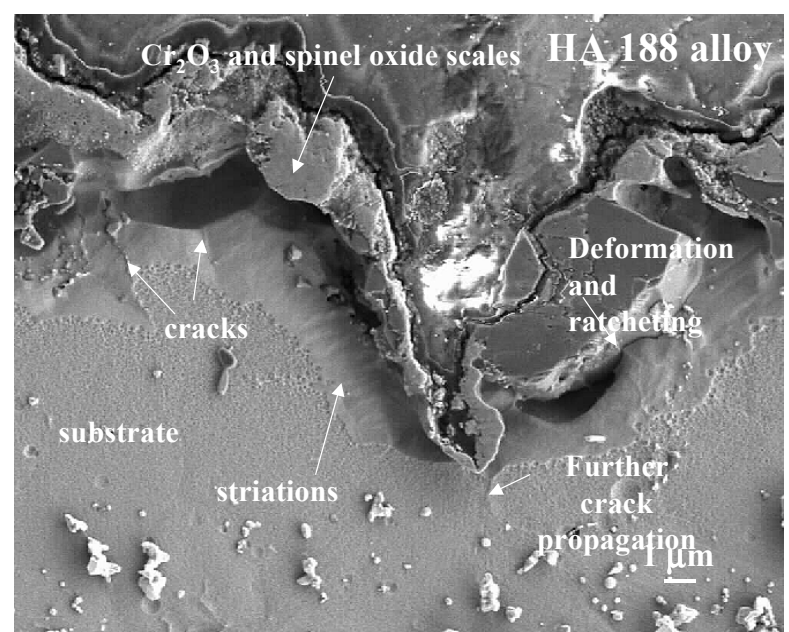

(a)

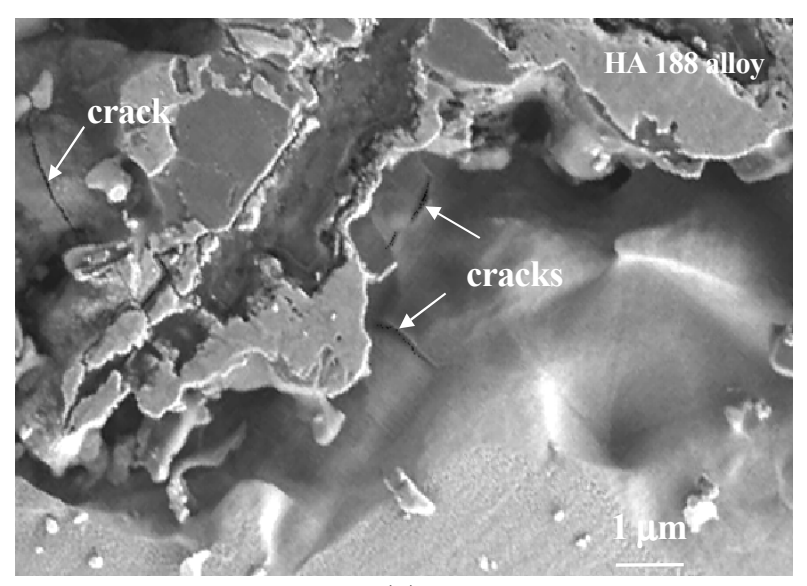

(c)

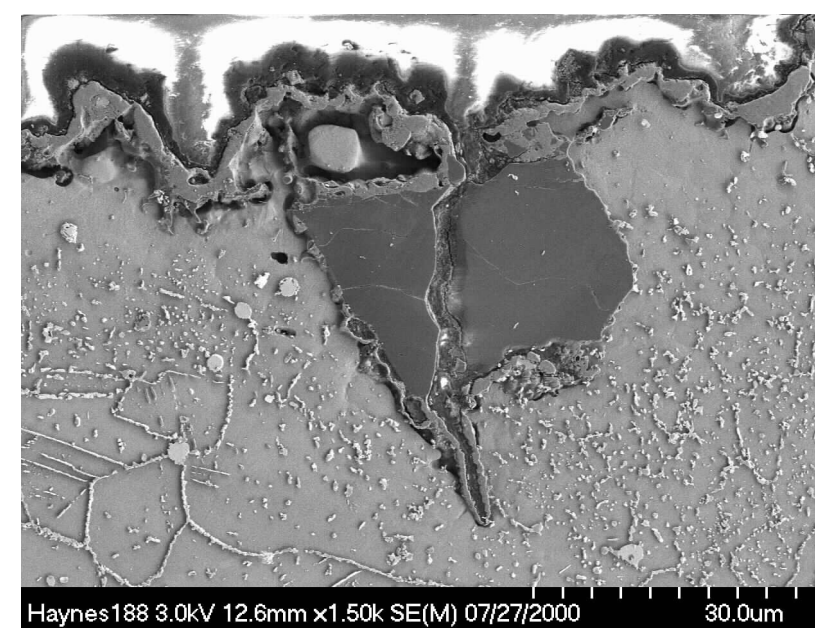

(b)

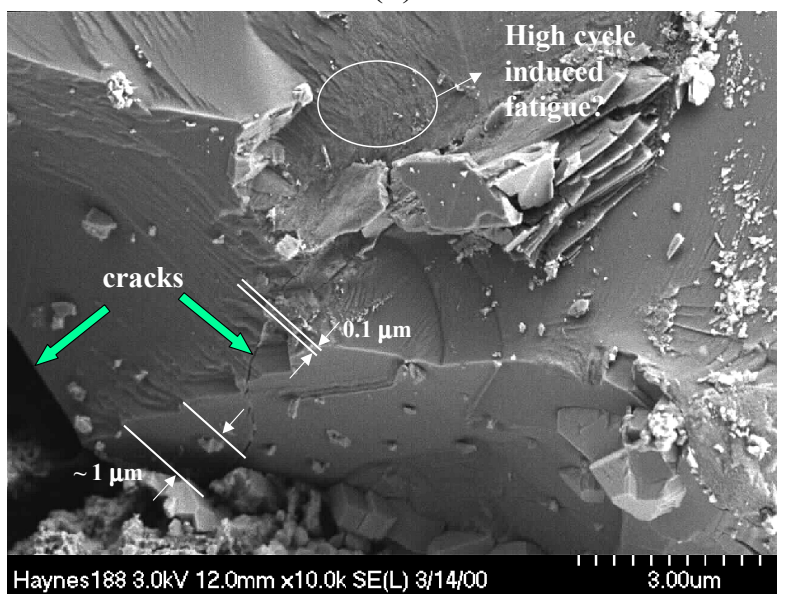

(d)

Figure 5.-Micrographs showing significant specimen oxidation, creep deformation and fatigue in the alloy substrate near the oxide scale/alloy interfaces for a Haynes 188 alloy specimen after the laser thermal cyclic testing. Oxide scale initial and further growth is detrimental to the materials fatigue resistance due to the thermal expansion mismatch stress induced creep-oxidation interactions. (a) and (b) Cross-sections of the specimen showing a surface crack penetrating into the alloy and associated oxide scale-alloy substrate fatigue striation and crack initiation. The carbides inclusions can facilitate the surface crack propagation under the surface impulsive thermal loading. (c) and (d) Microcracks and fatigue striations initiated in the alloy at the alloy/oxide interface under the surface cyclic thermal stresses.

As shown in fig. 6, the large induced creep strains, which accumulated at temperature under the thermal and stress gradients, can lead to a large tensile stress state at the surface upon cooling [4]. The specimen surface cracking can be initiated when the creep strain is high enough, and especially when the surface layer is greatly weakened by the presence of the oxidation scales, oxide and carbide inclusions, and grain boundary oxide decorations. As shown schematically in fig. 7, the cracks initiated can be further propagated under the enhanced laser thermal surface impulsive fatigue conditions because of the thermal expansion mismatch and thermal stress induced creep-oxidation interactions. The test results 


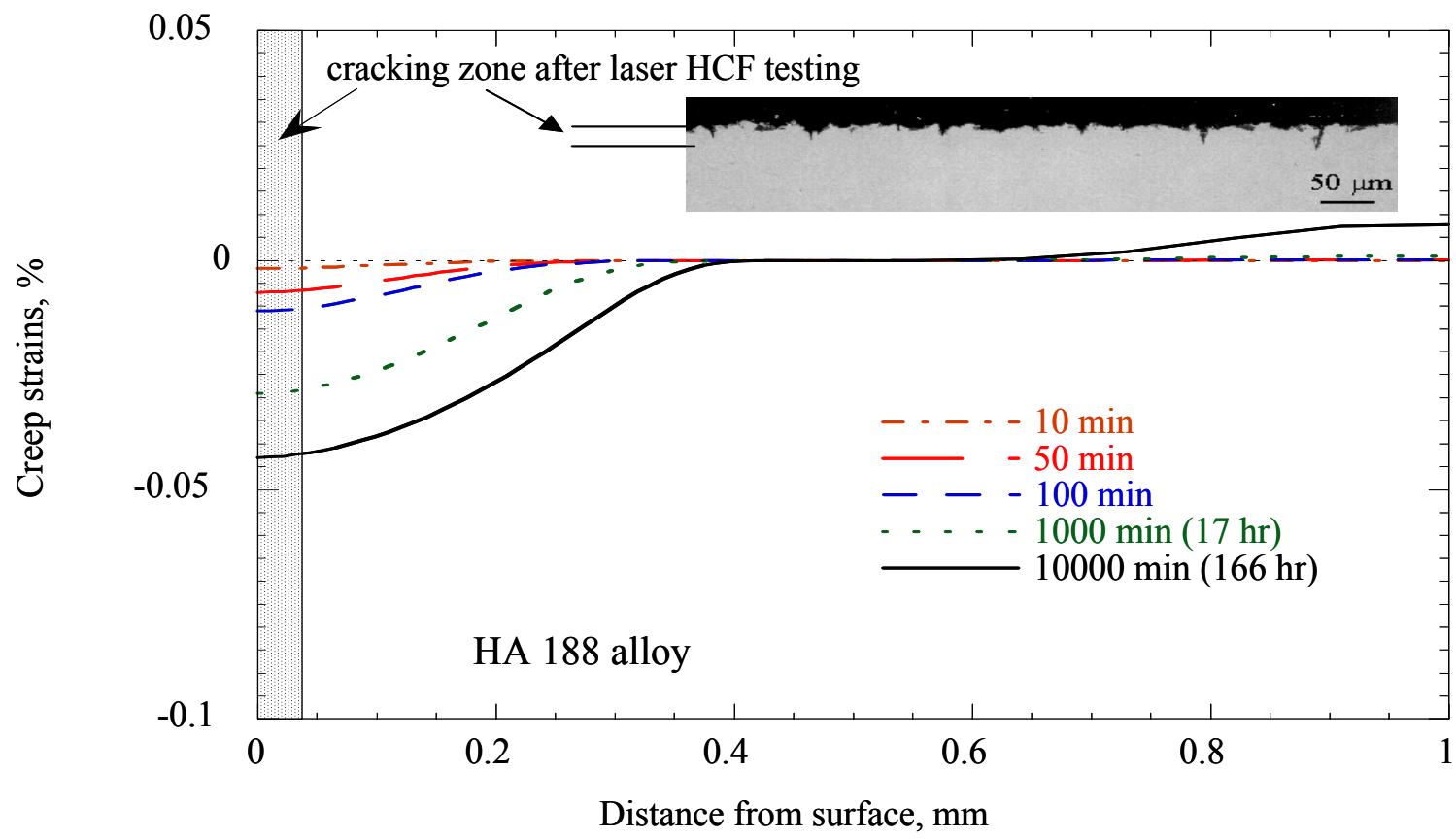

Figure 6.-Modeled creep strain distributions accumulated at temperature as a function of time under the laser thermal gradient testing. Also shown is the surface cracking morphology after the laser testing. Large compressive creep strains will occur at the specimen surface, which can lead to a large tensile stress state upon cooling. The specimen surface cracking can be initiated under high creep strains combined with the surface weakening due to oxidation.

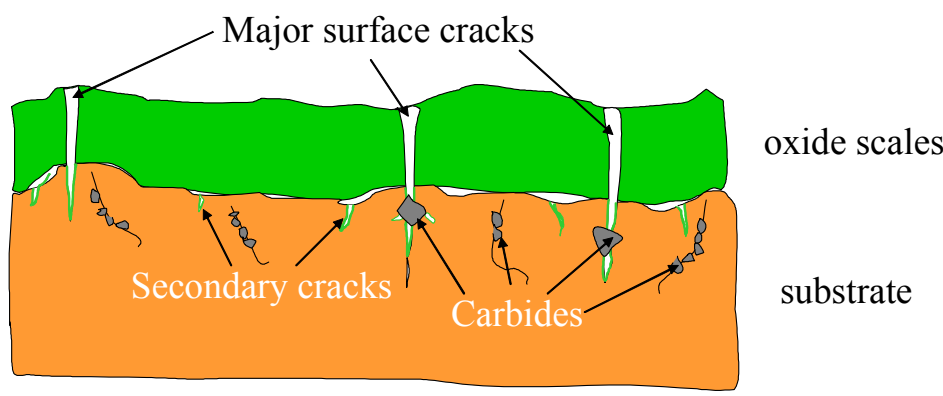

Figure 7.- Surface temperature swings can result in significant thermal cyclic stresses originating not only from the temperature gradient, but also from the CTE mismatch between thermally grown oxide scales and the substrate. The oxidation and creep of the substrate promotes surface crack initiation and propagation under the laser simulated CVCCE thermal HCF and LCF testing. 
suggest that oxidation and creep enhanced fatigue can be an important mechanism for materials surface crack initiation and propagation under the simulated impulsive thermal cyclic conditions.

Figure 8 shows the experimental results from the combined laser and four-point-bend thermomechanical fatigue tests for the Haynes 188 material. It can be seen that the enhanced fatigue interactions and thus reduced fatigue strength were observed for the material under the laser thermal pulse as compared to traditional mechanical HCF tests. The specimens with the larger sized cooling holes (diameter $0.76 \mathrm{~mm}$ also showed somewhat lower fatigue strengths as compared to those with smaller sized cooling holes. The superimposed laser surface impulsive fatigue testing showed a substantially increased fatigue crack initiation and later accelerated fatigue crack propagation due to the complex oxidation, creep and fatigue interactions.

The surface HCF damage also resulted in reductions in the fatigue life of the material under the subsequent mechanical high cycle fatigue tests $\left(100 \mathrm{~Hz}\right.$ at $\left.816^{\circ} \mathrm{C}\right)$. As shown in fig. 9 (a), it can be seen that the material fatigue strength was reduced by 10 to 12 percent for the specimens that were subjected to the initial laser pulse testing at the various temperatures and times, as compared to that for the asmachined specimens. Figure 9 (b) shows that the fatigue strength reductions are closely related to the surface temperature and exposure time of the pulsed laser treatment. The higher surface temperature and longer laser exposure time induced increased surface damage, further reducing the HCF Strength. The test results may further demonstrate the detrimental surface impulsive high cycle fatigue effect on the materials fatigue resistance.

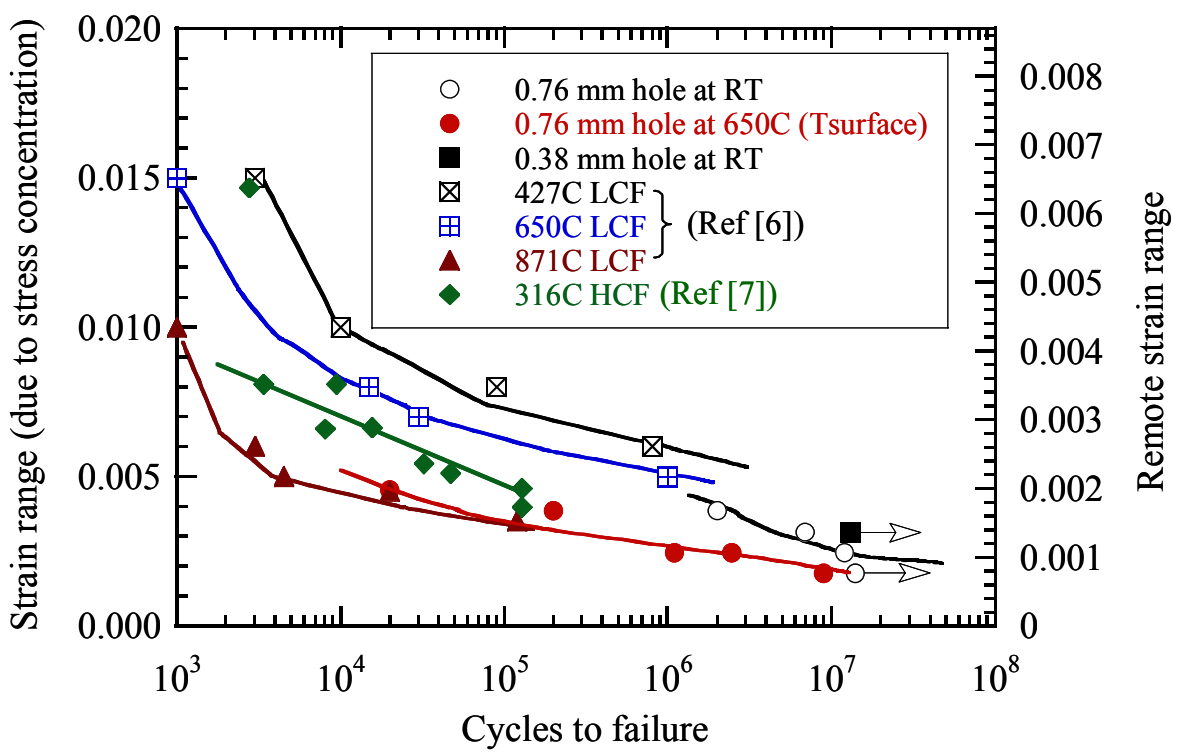

Figure 8.-Fatigue behavior of the Haynes 188 tested under the combined laser surface thermal high cycle fatigue and mechanical four-point bend fatigue test as compared to the conventional low cycle and high cycle fatigue tests. 


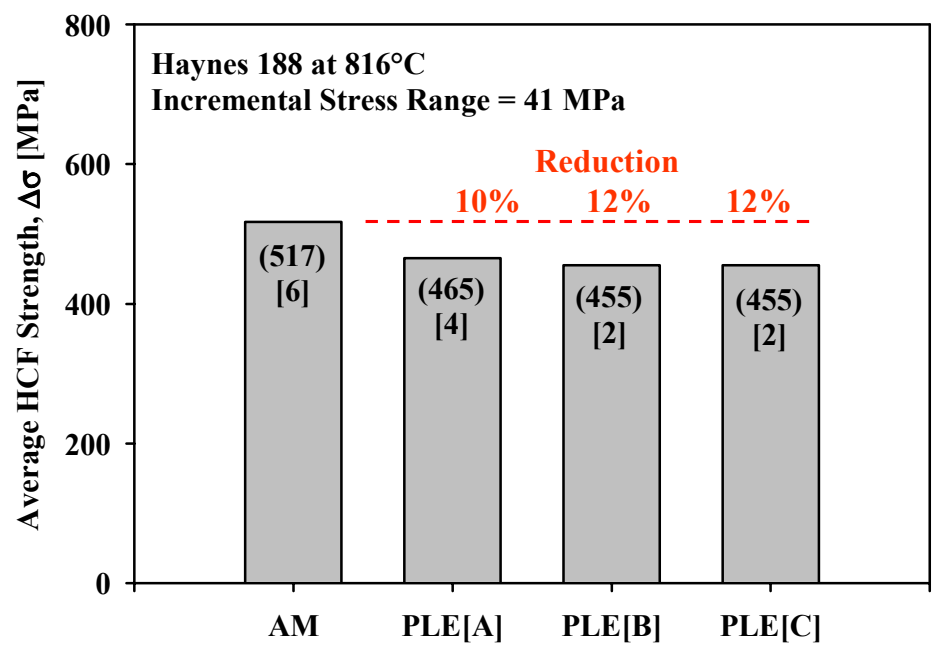

(a)

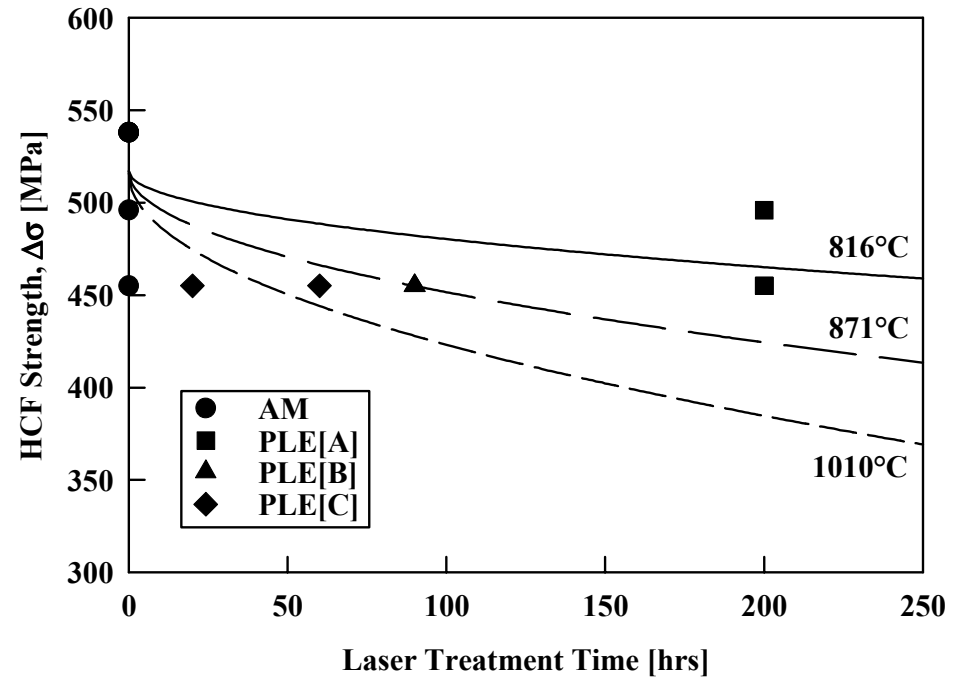

(b)

- AM: As-Machined (6 specimens-[6]):

- PLE[A] (6 specimens-[6]): 400 Cycles; 30 min. Duration; Maximum Temperature: $816^{\circ} \mathrm{C}\left(1500^{\circ} \mathrm{F}\right)$;

- PLE[B] (2 specimens-[2]): 180 Cycles; 30 min. Duration; Maximum Temperature: $871^{\circ} \mathrm{C}\left(1600^{\circ} \mathrm{F}\right)$;

- PLE[C] (2 specimens-[2]): 40 and 120 Cycles; 30 min. Duration; Maximum Temperature: $1010^{\circ} \mathrm{C}\left(1850{ }^{\circ} \mathrm{F}\right)$.

Figure 9.-The mechanical HCF behavior of Haynes 188 after the initial laser pulse thermal HCF treatment. (a) A 10 to 12 percent reduction in the fatigue strength was observed for the laser pretreated specimens as compared to the as-machined specimens. (b) The relationship between the HCF fatigue strength and the exposure time of the pulsed laser treatment as function of laser test temperature. 


\section{Conclusions}

A high cycle-enhanced pulse $\mathrm{CO}_{2}$ laser thermal fatigue approach was developed for evaluating candidate CVCCE combustor materials under simulated engine surface high frequency thermal and mechanical loading conditions. The thermal gradient and temperature swings can result in significant thermal cyclic stresses in the material system, and thus can induce surface cracking under surface oxidation, creep and the thermal cycling conditions. The oxidation- and creep-enhanced fatigue cracking was demonstrated experimentally. Fatigue striations of various sizes were observed at the cracked surfaces and oxide scale/alloy interfaces. Reduced fatigue strength was also demonstrated under combined laser thermo-mechanical fatigue testing for the candidate materials and under the mechanical testing of the laser pulse pre-exposed specimens. The test results indicated that oxidation and creep enhanced fatigue at the oxide scale/alloy interface was an important mechanism for the surface crack initiation and propagation under the laser induced surface impulsive fatigue conditions.

\section{References}

[1] S. Eidelman, W. Grossmann, and I. Lottati, "Review of Propulsion Applications and Numerical Simulations of the Pulsed Detonation Engine Concept," J. Propulsion, vol. 7, pp. 857-865, 1991.

[2] T.R.A. Bussing and G. Pappas, "An Introduction to Pulse Detonation Engines," in The 32nd Aerospace Sciences Meeting \& Exhibit, Indianapolis, Indiana, AIAA Paper No. 94-0263, January 10-13, 1994.

[3] T.R.A. Bussing, J.B. Hinkey, and L. Kaye, "Pulse Detonation Engine Preliminary Design Considerations," in the 30th AIAA/ASME/SAE/ASEE Joint Propulsion Conference, Indianapolis, Indiana, AIAA Paper No. 94-3220, June 27-29, 1994.

[4] D. Zhu, D.S. Fox, and R.A. Miller, "Laser High-Cycle Thermal fatigue of Pulsed Detonation Engine Combustor Materials Tested," Research and Technology 2000, NASA Glenn Research Center, Cleveland, Ohio, NASA TM-210605, 2001,19-22.

[5] S. Kalluri, G.R. Halford, "Damage Mechanisms in Bithermal and Thermomechanical fatigue of Haynes 188," Thermomechanical Fatigue Behavior of Materials, ASTM STP 1186, H. Sehitoglu, ed., American Society for Testing and Materials, Philadelphia, 1993, 126-143.

[6] Haynes Alloy 188 Brochure, Haynes International High Temperature Alloys, 1991.

[7] G.R. Halford, M.A. McGaw, R.C. Bill, and P.D. Fanti, "Thermomechanial and Bithermal Fatigue Behavior of Cast B1900+Hf and Wrought Haynes 188," Advances in Fatigue Lifetime Predictive Techniques, ASTM STP 1122, M.R. Mitchell and R.W. Landgraf, Eds., American Society for Testing and Materials, Philadelphia, 1992, 120-142. 
Public reporting burden for this collection of information is estimated to average 1 hour per response, including the time for reviewing instructions, searching existing data sources, gathering and maintaining the data needed, and completing and reviewing the collection of information. Send comments regarding this burden estimate or any other aspect of this collection of information, including suggestions for reducing this burden, to Washington Headquarters Services, Directorate for Information Operations and Reports, 1215 Jefferson Davis Highway, Suite 1204, Arlington, VA 22202-4302, and to the Office of Management and Budget, Paperwork Reduction Project (0704-0188), Washington, DC 20503.

\begin{tabular}{|l|l|l|}
\hline 1. AGENCY USE ONLY (Leave blank) & $\begin{array}{c}\text { 2. REPORT DATE } \\
\text { August } 2004\end{array}$ & $\begin{array}{c}\text { 3. REPORT TYPE AND DATES COVERED } \\
\text { Technical Memorandum }\end{array}$ \\
\hline
\end{tabular}

\section{TITLE AND SUBTITLE} 5. FUNDING NUMBERS

Effect of Surface Impulsive Thermal Loads on Fatigue Behavior of Constant Volume Propulsion Engine Combustor Materials

\section{6. $\operatorname{AUTHOR(S)}$}

Dongming Zhu, Dennis S. Fox, Robert A. Miller, Louis J. Ghosn, and Sreeramesh Kalluri

\section{PERFORMING ORGANIZATION NAME(S) AND ADDRESS(ES)}

National Aeronautics and Space Administration

John H. Glenn Research Center at Lewis Field

Cleveland, Ohio 44135-3191

WBS-22-708-03-04

1L162211A47A

8. PERFORMING ORGANIZATION REPORT NUMBER

E-14562

\section{SPONSORING/MONITORING AGENCY NAME(S) AND ADDRESS(ES)}

National Aeronautics and Space Administration

Washington, DC 20546-0001

and

U.S. Army Research Laboratory

Adelphi, Maryland 20783-1145
10. SPONSORING/MONITORING AGENCY REPORT NUMBER

NASA TM-2004-213084

ARL-TR-3258

\section{SUPPLEMENTARY NOTES}

Prepared for the International Conference on Metallurgical Coatings and Thin Films sponsored by the AVS Science and Technology Society, Advanced Surface Engineering Division, San Diego, California, April 19-23, 2004. Dongming Zhu, U.S. Army Research Laboratory, NASA Glenn Research Center; Dennis S. Fox and Robert A. Miller, NASA Glenn Research Center; and Louis J. Ghosn and Sreeramesh Kalluri, Ohio Aerospace Institute, 22800 Cedar Point Road, Brook Park, Ohio 44142. Responsible person, Dongming Zhu, organization code 5160, 216-433-5422.

12a. DISTRIBUTION/AVAILABILITY STATEMENT 12b. DISTRIBUTION CODE

Unclassified - Unlimited

Subject Categories: 23 and 26

Distribution: Nonstandard

Available electronically at http://gltrs.grc.nasa.gov

This publication is available from the NASA Center for AeroSpace Information, 301-621-0390.

\section{ABSTRACT (Maximum 200 words)}

The development of advanced high performance constant-volume-combustion-cycle engines (CVCCE) requires robust design of the engine components that are capable of enduring harsh combustion environments under high frequency thermal and mechanical fatigue conditions. In this study, a simulated engine test rig has been established to evaluate thermal fatigue behavior of a candidate engine combustor material, Haynes 188, under superimposed $\mathrm{CO}_{2}$ laser surface impulsive thermal loads $(30$ to $100 \mathrm{~Hz}$ ) in conjunction with the mechanical fatigue loads $(10 \mathrm{~Hz})$. The mechanical high cycle fatigue (HCF) testing of some laser pre-exposed specimens has also been conducted under a frequency of $100 \mathrm{~Hz}$ to determine the laser surface damage effect. The test results have indicated that material surface oxidation and creepenhanced fatigue is an important mechanism for the surface crack initiation and propagation under the simulated CVCCE engine conditions.

\begin{tabular}{|c|c|c|}
\hline \multicolumn{3}{|c|}{$\begin{array}{l}\text { 14. SUBJECT TERMS } \\
\text { Laser impulsive high and low cycle fatigue; Surface crack initiation and propagation; } \\
\text { Oxidation damage; Stress concentration }\end{array}$} \\
\hline $\begin{array}{l}\text { 17. SECURITY CLASSIFICATION } \\
\text { OF REPORT }\end{array}$ & $\begin{array}{l}\text { 18. SECURITY CLASSIFICATION } \\
\text { OF THIS PAGE }\end{array}$ & $\begin{array}{l}\text { 19. SECURITY CLASSIFICATION } \\
\text { OF ABSTRACT }\end{array}$ \\
\hline Unclassified & Unclassified & Unclassified \\
\hline
\end{tabular}

15. NUMBER OF PAGES

16. PRICE CODE

20. LIMITATION OF ABSTRACT

Standard Form 298 (Rev. 2-89)

Prescribed by ANSI Std. Z39-18 298-102 

